\title{
Design and Development of Prototype Cylindrical Parabolic Solar Collector for Water Heating Application
}

\author{
Kulkarni Hrushikesh Bhujangrao ${ }^{1 a^{*}}$
}

${ }^{a}$ School of Mechanical and Building Sciences, VIT University, Vellore-632014 (TN), India

\begin{abstract}
Concentrating collectors absorbs solar energy and convert it into heat for generating hot water, steam at required temperature, which can be further used for solar thermal applications. The developing countries like India where solar energy is abundantly available; there is need to develop technology for harnessing solar energy for power production, but the main problem associated with concentrating solar power technology is the high cost of installation and low output efficiency. To solve this problem, a prototype cylindrical parabolic solar collector having aperture area of $1.89 \mathrm{~m}^{2}$ is designed and developed using low cost highly reflecting and absorbing material to reduce initial cost of project and improve thermal efficiency. ASHRAE Standard 93, 1986 was used to evaluate the thermal performance and it was observed that this system can generate hot water at an average temperature of $50^{\circ} \mathrm{C}$ per day with an average efficiency of $49 \%$ which is considerable higher than flat plate solar collectors. Hot water produced by this system can be useful for domestic, agricultural, industrial process heat applications.
\end{abstract}

Keywords: cylindrical parabolic solar collector, solar energy, industrial process heat, solar thermal application.

Article History: Received Sept 19, 2015; Received in revised form Dec 23, 2015; Accepted February 2, 2016; Available online

How to Cite This Article: Bhujangrao, K.H. (2016). Design and Development of Prototype Cylindrical Parabolic Solar Collector for Water Heating Application. International Journal of Renewable Energy Development, 5(1), 49-55

http://dx.doi.org/10.14710/ijred.5.1.49-55

\section{Introduction}

Increasing Population, urbanization and industrialization demands energy at higher rate. India is facing serious problem of meeting adequate energy supply to customer at reasonable cost (Garg 2012; Kumar et al. 2010). India's energy requirement and forecast is as shown in Table 1. Demand of energy means electricity in industrial, agricultural and domestic sector is higher than other. According to Integrated energy policy report 2006, India has to maintain 8 to $10 \%$ economic growth rate to solve the issue of poverty and development goals. To maintain sustained growth of $8 \%$ till 2031, primary energy supply and electricity supply needs to be increased by 3 to 4 times and 5 to 7 times respectively than current rate of energy consumption. Energy in the form of electricity is generated in thermal power plant using conventional energy sources like coal, natural gas; crude oils as fuel, but availability of these sources are limited and may not support the process of sustainable development. Use of Fossil fuels for power production causes environmental pollution, global warming, ozone layer depletion and human health hazards (WEO 2013).

Tabel 1

India's energy demand and future scenario (IEP, 2006)

\begin{tabular}{lll}
\hline \multicolumn{1}{c}{ Sectors } & $\begin{array}{l}\mathbf{2 0 0 6 - 2 0 0 7} \\
\text { TWh/yr }\end{array}$ & $\begin{array}{l}\mathbf{2 0 5 0} \\
\mathbf{T W h} / \mathbf{y r}\end{array}$ \\
\hline Domestic & 121 & 994 \\
Commercial & 44 & 283 \\
Industry & 257 & 1202 \\
Transport & 12 & 532 \\
Agriculture and other & 133 & 156 \\
\hline Total & $\mathbf{5 6 7}$ & $\mathbf{3 1 6 8}$ \\
\hline Sources: IEA, 2009b; IEA, 2010a; IEA, 2009c
\end{tabular}

*Corresponding Author: +91-9788926660.

Email: hbkulkarni.coeo@gmail.com 
Citation: Bhujangrao, K.H. (2016). Design and Development of Prototype Cylindrical Parabolic Solar Collector for Water Heating Application. Int. Journal of Renewable Energy Development, 5(1), 49-55, http://dx.doi.org/10.14710/ijred.5.1.49-55

$\mathrm{P}$ a g e 150

Table 2 gives the detail information about house hold energy consumption in India. Rural people mostly use biomass such as wood and cow dung etc. which creates air pollution and health problems; in case of urban area mostly electricity is consumed for daily energy requirements.

Tabel 2

House hold energy consumption in India (IEP, 2006)

\begin{tabular}{|c|c|c|c|c|c|c|}
\hline \multirow{2}{*}{$\begin{array}{l}\text { Fuel } \\
\text { Type }\end{array}$} & \multicolumn{3}{|c|}{ Physical Units } & \multicolumn{3}{|c|}{ MToe } \\
\hline & Rural & Urban & Total & Rural & Urban & Total \\
\hline $\begin{array}{l}\text { Fire wood } \\
\text { and chips } \\
\text { (Mt) }\end{array}$ & 158.87 & 18.08 & 176.95 & 71.49 & 8.13 & 79.62 \\
\hline $\begin{array}{l}\text { Electricity } \\
\text { (BkWh) }\end{array}$ & 40.76 & 57.26 & 98.02 & 3.51 & 4.92 & 8.43 \\
\hline $\begin{array}{l}\text { Dung } \\
\text { Cake (Mt) }\end{array}$ & 132.95 & 8.03 & 140.98 & 27.92 & 1.69 & 29.61 \\
\hline $\begin{array}{l}\text { Kerosene } \\
\text { (ML) }\end{array}$ & 7.38 & 4.51 & 11.89 & 6.25 & 3.82 & 10.07 \\
\hline Coal (Mt) & 1.20 & 1.54 & 2.74 & 0.49 & 0.63 & 1.12 \\
\hline LPG (Mt) & 1.25 & 4.43 & 5.68 & 1.41 & 5.00 & 6.41 \\
\hline
\end{tabular}

To satisfy growing energy demand and solve environmental consequences, there is need to consider renewable energy sources as an alternative option for power generation, which are easily available and are clean i.e. doesn't create pollution. Renewable energy sources comprises of solar, wind, biomass, ocean energy etc. out of which, the solar energy has considered as one of the promising energy source for future. The solar energy can be used directly for electricity production or indirectly for solar thermal application. Sun is a very large and inexhaustible energy source. Solar radiations intercepted by Earth surface is approximately $18.8 \times 10^{11} \mathrm{MW}$, which are thousand times higher than present energy consumption rate (Sukhatme et al. 2008).

Concentrating solar collectors such as cylindrical parabolic troughs uses reflective mirrors or metal sheets to focus sunlight on absorber tube placed at focal point. Water (Thomas 1995) or synthetic oil (Montes et al. 2009) can be used as heat transfer fluid pumped throughout the system. Hot water is then sent to storage tank or steam is directed passed over turbine blade to produce electricity (Kalogirou et al. 1997). Cylindrical parabolic collectors can provide hot water and electricity for domestic, industrial (Mekhilef et al. 2011), agricultural and commercial applications (Kalogirou 2004). A detail literature review is done to study the research and development activities done for implementing cylindrical parabolic collector technology for various applications.

Thermal performance of parabolic trough collectors can be improved by direct steam generation using water as working fluid instead of oil. Odeh et al. (1998) developed a mathematical model to evaluate thermal loss through parabolic trough using Syltherm
800 oil as heat transfer fluid at Sandia national laboratory. This model considers absorber tube temperature rather than working fluid temperature so this model is applicable to all type of working fluids. Water was used for direct steam generation and it is observed that heat losses in case of oil are more than water, other factor such as mass flow rate, inlet water temperature, radiation level etc. affects thermal performance of trough were optimized using designed simulation model.

Price et al. (2002) have reviewed current status, research and development activities taken towards enhancement in the performance of parabolic trough technology. Review put focus on the improvement in trough design, support structure, reflector, receiver, heat transfer fluid and storage, operation and maintenance and plant economics. Parabolic trough technology can compete with conventional power plant technology but there is need to reduce of overall cost of project and improve efficiency of power generation.

Nasir (2004) has fabricated a parabolic trough collector of two plate plate's type and tested for air heating application. Thermal analysis of trough was performed on data collected for three days form morning 10AM to 5PM at different mass flow rate of air. Trough manufactured by locally available material can generate hot air up to $97^{\circ} \mathrm{C}$ with $65 \%$ efficiency. This system was found to be most suitable for household and industrial drying purpose in middle and northern part of Nigeria where abundant solar radiations are available.

Mokhtari et al. (2007) observed that in the process of designing and installation of parabolic collectors requires about half of the cost of total installation cost of power plant, so there is necessity of optimization of various parameters of parabolic collectors like concentration ratio, rim angle, length of collector, mass flow rate of heat transfer fluid etc.to achieve highest efficiency with least cost. A computer code was written in MATLAB to obtain economic performance of collector and same code was used to predict performance collectors manufactured by Luz Company. An energy cost analysis was performed to study the competitiveness of solar power plant with the conventional power plants. Optimization shows that the overall performance in terms of economy was strongly depend on various input parameters and properly controlled parameter can give best thermal performance of solar collectors.

Kinyua et al. (2011) have fabricated a roof top parabolic trough for steam production. Three different reflector materials were selected and thermal performance of trough was evaluated with and without glass cover. Maximum temperature obtained by this system was $248.3^{\circ} \mathrm{C}$ with an average value of steam was $150^{\circ} \mathrm{C}$. It was observed that trough covered with glass yields 50 to $55 \%$ efficiency which is $20 \%$ more as compared to trough without glass cover further 
efficiency can be enhanced by installing automatic tracking system.

A computation program was written by Sangotayo et al. (2011) in C++ language to investigate the heat transfer phenomenon in absorber tube of cylindrical parabolic solar collector in Ogbomosho climatic conditions. Different heat transfer fluids, twisted tape of ratio and various system parameters were considered to study the effect of on performance of trough. It was observed that oil has high heat transfer capacity, twisted tape increases the friction factor causes enhanced heat transfer with Instantaneous efficiency of 47.38\%.

Rongrong et al. (2013) developed a dynamic model of parabolic trough collector considering oil as heat transfer fluid by Simple Euler transformation method. Main objective of the work was to study heat transfer analysis between glass cover, receiver tube and heat transfer oil under variable conditions and altering system parameters over a period of time. Real operating plant data of SEGS-VI collected during summer, spring days and used to validate this mathematical model. This dynamic model can be used for forecasting performance of parabolic trough power plant under varying atmospheric and working conditions.

Parabolic trough collectors can also be used for water desalination system because of its can concentrate high amount of heat from solar radiation (Kolagirou 1998; Hegazy et al. 2007).

From above study it was observed that, high cost of installation and low thermal efficiency of are the main problem associated with cylindrical parabolic collector technology and there is need to reduce cost and enhance the efficiency of system to make suitable for various applications (Pitz-Paal et al. 2007). This paper deals with design and fabrication of prototype cylindrical parabolic collector with low cost locally sourced material for water heating application. This will reduce the use of electricity for water heating and can satisfy domestic and industrial process heat demands (Weiss et al. 2008).

\section{Design and construction of cylindrical parabolic solar collector}

Concentration ratio is an important parameter used to describe the amount of solar energy concentrated by cylindrical parabolic collector. Geometric concentration ratio is defined as the ratio of area of aperture to the surface area of receiver tube of solar collector (Stine et al. 2006)

$$
C R_{g}=\frac{A_{a}}{A_{r}}
$$

where:

- $\mathrm{CR}_{\mathrm{g}}$ is geometric concentration ratio,
- $\mathrm{A}_{\mathrm{a}}$ is the area of aperture $\left(\mathrm{m}^{2}\right)$,

- $\mathrm{A}_{\mathrm{r}}$ is the area of absorber tube $\left(\mathrm{m}^{2}\right)$,

Concentration of solar radiation can be enhanced by reducing area of absorber tube and increasing area of aperture. Reduction in absorber tube area may help in reducing thermal losses from collector and improving thermal efficiency (Stine et al. 2006). Width, length of collector and outer diameter of absorber tube selected within range of sizes available in market so as to achieve higher concentration ratio.

$$
\begin{gathered}
C R_{g}=\frac{\left(W-D_{o}\right) \times L}{\pi \times D_{o} \times L} \\
C R_{g}=\frac{(1030-19) \times 1082}{\pi \times 19 \times 1082} \\
C R_{g}=16.94 \cong 17
\end{gathered}
$$

where:

- $\mathrm{CR}_{\mathrm{g}}$ is geometric concentration ratio,

- W width of collector $(\mathrm{m})$,

- L length of collector (m),

- $\mathrm{D}_{\mathrm{o}}$ Outer diameter of absorber tube (m),

Equation 1 shows the important relationship between the width and depth of cylindrical parabolic collector and equation 3 is used to calculate the focal point where absorber tube can be placed.

$$
\begin{aligned}
& y=\frac{d}{(0.5 \times W)^{2}} x^{2} \\
& f=\frac{W^{2}}{16 \times d}
\end{aligned}
$$

where:

- $\mathrm{f}$ is the focus of parabola,

- W width of collector (m),

- d depth of collector (m),

$$
f=\frac{1030^{2}}{16 \times 300}=221.02 \mathrm{~mm}
$$

Figure1 shows the CAD model of cylindrical parabolic collector having desired width, depth, and exact location of absorber tube. Wireframe 3D model of whole collector is shown in Figure2. 


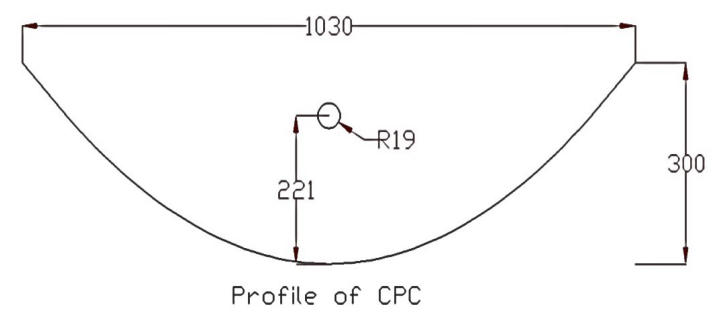

Figure 1 Profile of CPC and location of absorber tube

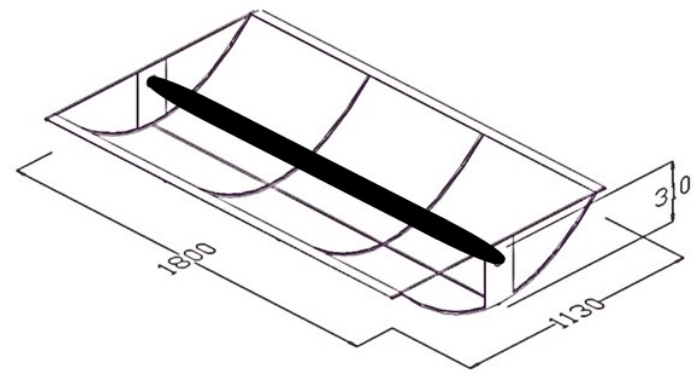

Figure 2 CAD wireframe model of full cylindrical parabolic collector

Cylindrical parabolic collector consist of mild steel reflective sheet curved into desired shape, to reflect maximum solar radiations and coated with silver foil of 0.85 reflectivity. Absorber tube made up of mild steel placed at focal point and pass through the length of collector is coated with black copper of absorptivity of 0.94. Heat transfer fluid i.e. water passes through solar collector and get heated due to absorption of solar energy in the form of heat. Support structure fabricated using steel for providing mechanical support to whole system. Table 3 gives detail specification of prototype cylindrical parabolic collector.

Tabel 3

Specification of prototype cylindrical parabolic collector

\begin{tabular}{ll}
\hline Items & Values \\
\hline Collector Width & 1.03 meter $(\mathrm{m})$ \\
Collector length & $1.82 \mathrm{~m}$ \\
Focal distance & $0.221 \mathrm{~m}$ \\
Receiver inner diameter & $0.017 \mathrm{~m}$ \\
Receiver outer diameter & $0.019 \mathrm{~m}$ \\
Concentration ratio & $16.94 \sim 17$ \\
Water flow rate & 4 litres $/$ hour \\
Rim angle & $134.52^{\circ}$ \\
\hline
\end{tabular}

\section{Experimentation and performance testing}

Experimental setup and equipment's used for data collection is shown in figure3. Solar collector is connected with both hot and cold water storage tank with well insulated pipe to avoid heat loss. Cold water storage tank is placed 6 feet above ground to facilitate natural flow of water through system and cold water storage tank is well insulated and placed on ground.

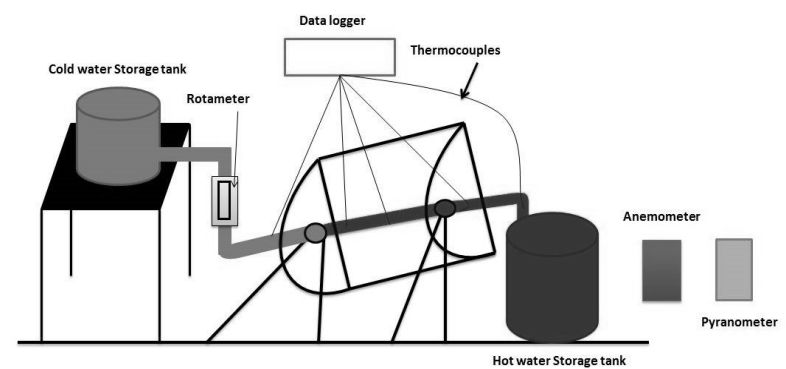

Figure 3 Experimental setup of cylindrical parabolic solar collector for performance testing

Rotameter is connected in between cold water storage tank and collector to measure and control flow rate of water. K-type thermocouples are used to record temperature at various locations such as ambient, inlet, outlet and of absorber tube. Electronic controlled data logger system is used to collect data at regular interval of 30 minutes and is stored in computer memory. Anemometer is device used to measure wind speed flowing over the trough and Pyranometer used for recording solar beam radiations falling on the aperture area of the trough. There is no relationship between location of anemometer and Pyranometer with respect to collector; it can be kept near the experimental setup. Manual tracking system was adopted with North-South (N-S) tracking mode for maintaining solar beam radiation perpendicular to aperture area. Test was conducted as per (ASHRAE Standard 93, 1986) and the thermal performance was evaluated using the detail procedure mentioned in book (Sukhatme et al. 2008). Data was recorded after each half an hour from morning $10 \mathrm{AM}$ to $4 \mathrm{PM}$ during month of May at Department of Technology, Shivaji University Kolhapur (M.S.) India, (Latitude: $16.42^{\circ} \mathrm{N}$, Longitude: $74.13^{\circ} \mathrm{W}$ ).

\section{Results and Discussion}

Figure4 shows the variation of beam radiation of day time. It is observed that beam radiation increases as day time increases from morning $10 \mathrm{AM}$ to $12 \mathrm{PM}$. Variation in the value of beam radiation was observed due to presence of clouds. Clouds deflect the path of radiations get diffused and concentrating collectors can't collect diffuse radiations (WB Stine et al. 2001, Mitra et al. 2014). Beam radiation intensity is higher during clear sky condition. Maximum radiation 
available was $1050 \mathrm{~W} / \mathrm{m}^{2}$ and lowest value was 820 $\mathrm{W} / \mathrm{m}^{2}$. This range of radiation is sufficient producing hot water at desired temperature.

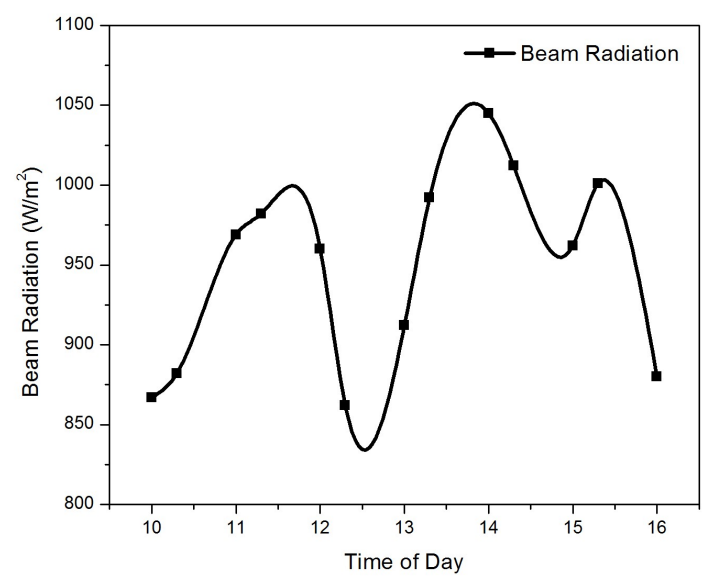

Figure 4 Available beam radiation over day time

Fluctuations in mean absorber tube temperature and water outlet temperature due to change in beam radiation is shown in Figure5 over day time. Comparing Figure 4 and 5, it can be stated that, there is linear relationship between beam radiation and tube and water outlet temperature (Arasu et al. 2006). Mean absorber tube temperature and water outlet temperature was maximum at $1 \mathrm{PM}$ and slowly reduces up to evening. Maximum water outlet temperature was observed to be $55^{\circ} \mathrm{C}$. Effect of clouds on both temperatures was observed during 12.30 PM.

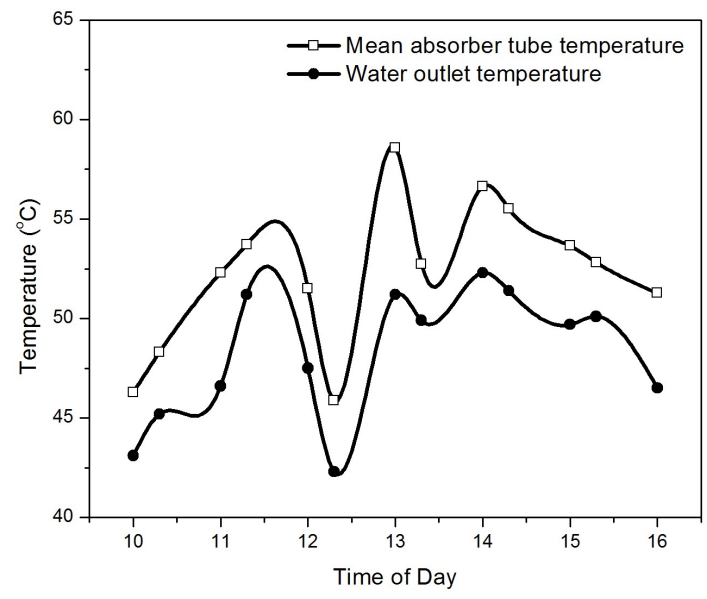

Figure 5 Mean absorber tube temperature and water outlet temperature over day time

Approximately 5 to $8^{\circ} \mathrm{C}$ temperature difference were observed in between absorber tube and water outlet temperature due to conductive and convective heat losses.

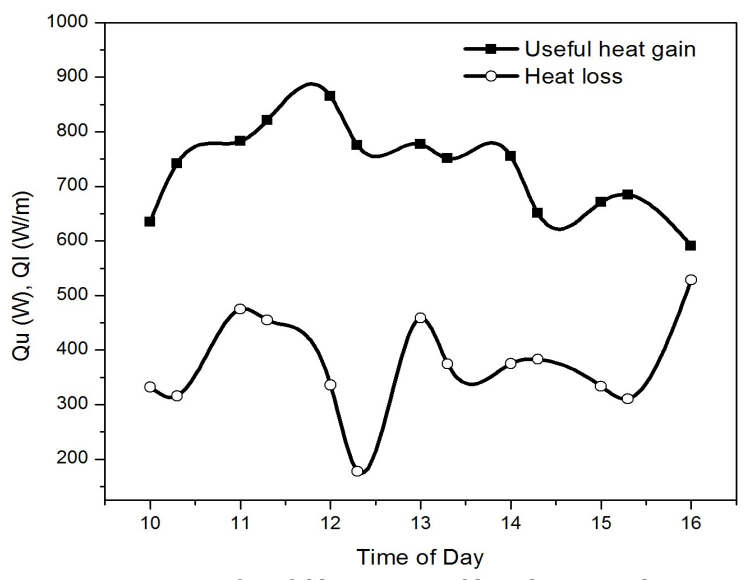

Figure 6 Variation of useful heat gain and heat loss over day time

Figure6 shows the relationship between useful heat gain and heat loss. Both heat gain and heat loss depends on incident beam radiation, reflector and absorber efficiency and wind speed. There is inverse relationship between heat gain and heat loss. During noon useful heat gain increases as beam radiation increases and there is reduction in heat losses. At $4 \mathrm{PM}$ and onwards it was observed that beam radiation and atmospheric temperature decreases which causes the flow of heat out of collector because of conduction, convection due to which heat loss increases suddenly and reduction in heat gain (Yaghoubi et al. 2013).

Effect of wind speed on water outlet temperature is as shown in figure figure7. Wind speed is scaled by $1: 10$ for easy interpretation. Convective heat loss increases as wind speed increases. Air carries away heat from collector when speed is high. Prototype cylindrical parabolic collector is open and not covered with glass, so there is chance of heat loss from absorber tube.

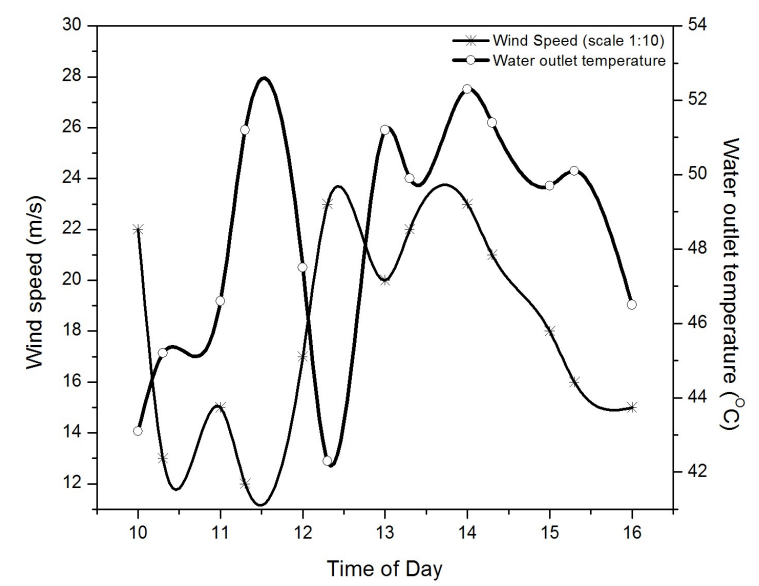

Figure 7 Effect of wind speed on water outlet temperature

During $10 \mathrm{AM}$ to $12 \mathrm{PM}$ water outlet temperature rises steadily as beam radiation increases and at the same time wind speed was very low so very less heat 
Citation: Bhujangrao, K.H. (2016). Design and Development of Prototype Cylindrical Parabolic Solar Collector for Water Heating Application. Int. Journal of Renewable Energy Development, 5(1), 49-55, http://dx.doi.org/10.14710/ijred.5.1.49-55

$\mathrm{P}$ a g e $\mid 54$

loss was observed. Between $12 \mathrm{PM}$ to $1 \mathrm{PM}$ there was sudden rise in wind speed from $1.2 \mathrm{~m} / \mathrm{s}$ to $2.4 \mathrm{~m} / \mathrm{s}$ which cause high amount of heat loss which causes water outlet temperature reduced from $53^{\circ} \mathrm{C}$ to $42^{\circ} \mathrm{C}$. During evening water outlet temperature decreases because of fall in beam radiation and atmospheric temperature. Outlet water temperature can be further improved by covering whole trough by glass cover which doesn't allow the flow of air over absorber tube and convective heat losses can be minimised (Kulkarni 2015).

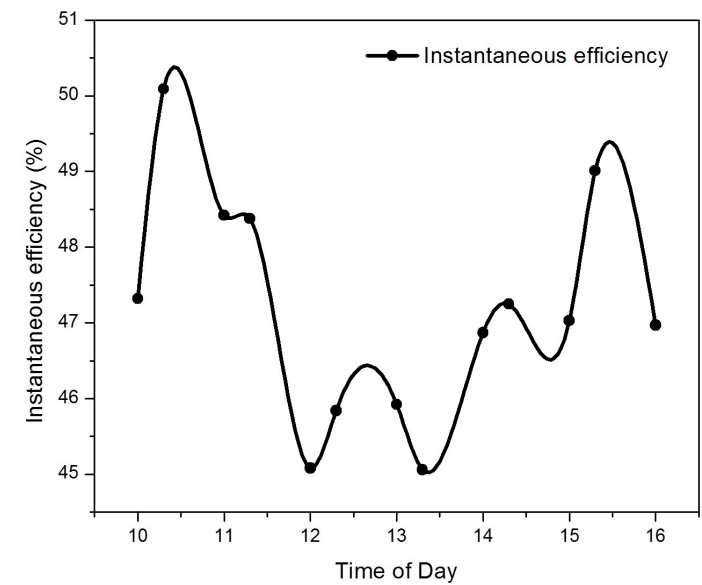

Figure 8 Instantaneous efficiency of collector over time of day

Instantaneous efficiency is mainly dependent on incident beam radiation, useful heat gain, heat loss and amount of heat transferred to working fluid. Instantaneous efficiency was calculated after each half an hour for a day and it is plotted in figure8. Morning time favours low wind speed, higher beam radiation so there is more useful heat gain and increase in instantaneous efficiency, but during noon heat loss increased because of higher wind speed and there is reduction in conversion efficiency. Highest efficiency was $51 \%$ achieved at $1000 \mathrm{~W} / \mathrm{m}^{2}$ beam radiation nearly equal to Arasu et al (2007) with low cost material and installation.

\section{Conclusion}

Considering higher demand of energy and to reduce the dependency on fossil fuel, a prototype cylindrical parabolic solar collector was designed and developed using locally sourced low cost material for water heating application. Prototype was tested as per ASHRAE Standard 93, 1986 and thermal performance was evaluated. During test it is observed that increase in wind speed causes more convective heat loss of heat and vice versa. Beam radiation directly affects the instantaneous efficiency and water outlet temperature. This system can generate hot water at an average temperature of $50^{\circ} \mathrm{C}$ throughout day at normal atmospheric temperature. This prototype system can be commercialized for domestic as well industrial process heat application where hot water is primary demand.

\section{Acknowledgments}

The author is thankful to Prof. N.N. Shinde (Department of Technology, Shivaji University, Kolhapur (MH) India) and Mr. Shailesh Patil for providing support during fabrication and experimentation work.

\section{Abbreviations \\ TWh/yr - Terawatt per year \\ Mt- Metric tons}

\section{References}

Arasu, A. V., \& Sornakumar, T. (2008). Life cycle cost analysis of new FRP based solar parabolic trough collector hot water generation system. Journal of Zhejiang University SCIENCE A, 9(3), 416-422.

Emmanuel 0. Sangotayo, Mufutau A. Waheed, (May 2011 Spring), Parametric Study of Heat Characteristics of Fluid in Cylindrical Parabolic Concentrating Solar Collector., The Pacific Journal of Science and Technology, 12(1).

Garg, P. (2012). Energy scenario and vision 2020 in India. Journal of Sustainable Energy \& Environment, 3, 7-17.

Hegazy, A. S., \& ElMadany, M. M. (2007). Design and experimental testing of a solar parabolic trough collector with its tracking system for salt-water desalination in arid areas of Saudi Arabia.

Kulkarni Hrushikesh Bhujangrao (2015), Effect of top glass cover on thermal performance of cylindrical parabolic collector, International Research Journal of Engineering and Technology (IRJET), 2(8)-2015.

Kumar, A., Kumar, K., Kaushik, N., Sharma, S., \& Mishra, S. (2010). Renewable energy in India: current status and future potentials. Renewable and Sustainable Energy Reviews, 14(8), 2434-2442.

Kawira, M., Kinyua, R., \& Kamau, J. N. (2013). Prototype parabolic trough solar concentrators for steam production. Journal of Agriculture, Science and Technology, 14(2).

Kalogirou, S. A. (2004). Solar thermal collectors and applications. Progress in energy and combustion science, 30(3), 231-295.

Kalogirou, S. (1998). Use of parabolic trough solar energy collectors for sea-water desalination. Applied Energy, 60(2), 65-88.

Kalogirou, S., Lloyd, S., \& Ward, J. (1997). Modelling, optimisation and performance evaluation of a parabolic trough solar collector steam generation system. Solar Energy, 60(1), 49-59.

Mekhilef, S., Saidur, R., \& Safari, A. (2011). A review on solar energy use in industries. Renewable and Sustainable Energy Reviews, 15(4), 1777-1790.

Mokhtari, A., \& Yaghoubi, M. (2007). Thermo-Economic Design of a Parabolic Solar Collector. In Proceedings of the Middle East Mechanical Engineering Conference MEMEC 4-7.

Mitra, I., Chhatbar, K., Kumar, A., Giridhar, G., Vashistha, R., Meyer, R., \& Schwandt, M. (2014). Solmap: Project In India's Solar Resource Assessment.International Journal of Renewable Energy Development (IJRED), 3(3), 207-216.

Montes, M. J., Abánades, A., Martinez-Val, J. M., \& Valdés, M. (2009). Solar multiple optimization for a solar-only thermal power plant, using oil as heat transfer fluid in the parabolic trough collectors. Solar Energy, 83(12), 2165-2176.

Nasir, A. (2004). Design, construction and experimental study of the thermal performance of a parabolic cylindrical trough solar air heater. AU Journal of Technology, 8(1), 21-26. 
Odeh, S. D., Morrison, G. L., \& Behnia, M. (1998). Modelling of parabolic trough direct steam generation solar collectors. Solar energy, 62(6), 395-406.

Pitz-Paal, R., Dersch, J., Milow, B., TÃšllez, F., Ferriere, A., Langnickel, U., ... \& Popel, O. (2007). Development steps for parabolic trough solar power technologies with maximum impact on cost reduction. Journal of Solar Energy Engineering, 129(4), 371-377.

Price, H., Lupfert, E., Kearney, D., Zarza, E., Cohen, G., Gee, R., \& Mahoney, R. (2002). Advances in parabolic trough solar power technology. Journal of solar energy engineering, 124(2), 109-125.

Policy,I.E.(2006). Report of the Expert committee, Planning commission, Government of India, Accessed on 26 October 2015.http://planningcommission.nic.in/reports/genrep/ rep intengy.pdf, Accessed on 7 June 2015.

Rongrong, Z., Yongping, Y., Qin, Y., \& Yong, Z. (2013). Modeling and Characteristic Analysis of a Solar Parabolic Trough System: Thermal Oil as the Heat Transfer Fluid. Journal of Renewable Energy, 2013.

Stine, W. B., \& Geyer, M. (2001). Power from the Sun. www.powerfromthesun.net. Accessed on 7 June 2015

Standard, A. S. H. R. A. E. (1986). Standard 93-1986. Method of testing to determine the thermal performance of solar collectors
American Society for Heating, Refrigerating and Air-conditioning Engineers. Atlanta, USA.

Sukhatme, K., \& Sukhatme, S. P. (1996). Solar energy: principles of thermal collection and storage. Tata McGraw-Hill Education.

Thomas, A. (1996). Solar steam generating systems using parabolic through concentrators. Energy conversion and management, 37(2), 215-245.

van der Hoeven, M.,(2013). World Energy Outlook 2013.

Valan, A. A., \& Sornakumar, S. T. (2006). Performance characteristics of the solar parabolic trough collector with hot water generation system. Thermal science, 10(2), 167-174.

Weiss, W., \& Rommel, M. (2008). Process heat collectors. State of the Art within Task, 33

Yaghoubi, M., Ahmadi, F., \& Bandehee, M. (2013). Analysis of heat losses of absorber tubes of parabolic trough collector of Shiraz (Iran) solar power plant.Journal of Clean Energy Technologies, 1(1), 33-37 